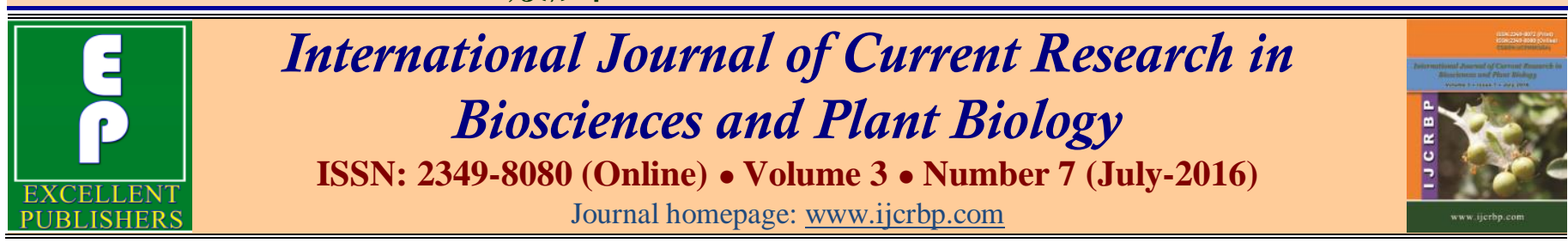

\title{
Effects of Different Growth Media on Propagation of Horticultural Plant, Mussaenda philippica (Queen of Philippines)
}

\author{
S.O. Okanlawon, K. M. Babatunde*, M. A. Salau, O. A. Adekanmbi and A. R. Jmoh \\ Department of Agricultural Technology, The Oke-Ogun Polytechnic, Saki, Oyo State, Nigeria \\ *Corresponding author.
}

\begin{abstract}
A bstract
An experiment was conducted to investigate suitable growth media for propagation of Mussaenda philippica (Queen of Philippines) plant. Nine different growth media were used; Topsoil, Poultry manure, River sand, Sawdust, Topsoil + Poultry manure, Topsoil + Sawdust, Topsoil + River sand + Poultry manure, Topsoil + Sawdust + Poultry manure and Topsoil + Sawdust + Poultry manure + River sand, replicated four times and arranged in a completely randomized design (CRD). This research relates generally to the use of different growth media for propagation of the horticultural plant; Mussaenda philippica. Chemical analysis of the growth media were examined and data collected were subjected to statistical analysis using t-test, fourteen weeks after planting; readings were taken at two weeks interval. The results showed varied significant levels with regards to the effects of the growing media on the measured agronomic parameters, except on the plant height which indicated non-significance $(p<0.05)$ effect, however, Topsoil + Sawdust + Poultry manure (T8) was the best among all the growth media used for propagation because it had a more pronounced positive significant $(p=0.0001)$ effects on number of branches and leaves, and $(p<0.05)$ on number of roots.
\end{abstract}

\section{Article Info}

Accepted:19 May 2016

Available Online: 06 July 2016

Keywords

Growth media

Landscape

Mussaenda philippica

Propagation

\section{Introduction}

Production of Mussaenda seedlings tend to become important in the context of social and economic changes in Nigeria. This is because since the oil boom era, most Nigerians desired to beautify their environment (Dirr et al., 1987). Mussaenda, owing to its diversified growth habit, exquisite shape, variation in sizes and form, attractive colour and innumerable varieties. It is an item for garden decoration and general landscaping work, it is also grown as pot plants and there are varieties which are suited for planting in the rock garden. Mussaenda philippica is a difficult-to-root plant, resulting in low multiplication which often contributed to its high sales cost and scarcity in the market. Mussaenda philippica could be the most valued plant in the modern landscape and probably the most misunderstood plant. In order to establish an efficient procedure by which large number of planting materials can be produce, certain factors which influence the rooting of the Mussaenda cutting must be studied (Ball et al., 2003). The Mussaenda used in landscapes are open, somewhat scrambling shrubs, and range from $0.6 \mathrm{~m}-4.6 \mathrm{~m}$ in height, depending upon the species. In the wild, some can climb $9 \mathrm{~m}$ into surrounding trees; though in cultivation they rarely reach that size. Leave are opposite, bright to dark green, and rounded to elliptic. They are often quiescently covered with short, fine hairs and prominently veined (Kyle and John, 1996). Plants propagation involves the use of nonsexual plant organs such as leaves, stems, and roots. A cutting can be rooted within six weeks (Mac Donald, 1987). To form new plants, they are cut from parent 
plants called stock plants. The environment required for growing cuttings is the same as for germinating seeds, warmth, moisture and a growing medium (Van Pattern et al., 1997). Vegetative propagation is based on using part of an existing stock to generate new plants. These daughter plants will have traits identical to those of the plants from which they were derived (Arbury et al., 1997). However, vegetative propagation is equally if not more, important in horticulture for several reasons. First it is often faster than seed propagation. Most important, exact genetic duplicate are called clones and are essential or preservation of desirable characteristics such as fast growth or high yield are not in sexual reproduction (Bajaj et al., 1992).

Growth media plays a key role in quality and production of flowering plants. Natural soil and peat are the most used growing substrates for the container production of annual and perennial ornamental plants (Tariq et al., 2012). Growth media containing peat is commercially an expensive and non-reusable component but developing inexpensive alternatives by the use of nutrient-rich organic media can potentially results in reduction of fertilization and irrigation rates as well as also decrease nursery costs (Wilson et al., 2002).

Growth soil mixes are the most important factors for the quality production of flowers in floriculture. The growing medium that supports and surrounds the rooting area will determine whether roots will form or not. The main requirement is that it should drain quickly to admit air to the rooting area, yet retain some moisture. There is no one superior rooting medium. Many combinations of materials are used; including the following five - two parts (by volume) sand and one part peat moss, one part perlite and one part vermiculite, pure vermiculite pure perlite and pure sand (Razdan, 2003). Many brands of pre-mixed media are available. They are sold under the name "House plant soil" or sometimes "Cacti soil" or "African violet soil" although most contain no soil at all. They are completely satisfactory for indoor plant growing, although they can be relatively expensive when used in quantity. A few particularly, the types sold as Cacti could be improved by the addition of more coarse sand. The sand adds weight to the medium and reduces the problem of a top-heavy plant that tips easily (Nau et al., 1999).

The organic component of the growth medium is very important as the plant derived nutrient from it; the waterholding capacity is high, and have a spongy structure resistant to packing. In addition, its nutrient-holding ability and cation-exchange capacity enable organic component to function as a nutrient reservoir. Coarse aggregate component improve the drainage of the medium due to the angular shape of each particle, creating large or macro pore spaces. These pore spaces increase the drainage rate. In general, coarse aggregates have a hard structure and poor water-holding and cationexchange capacities (Razdan, 2003). The objective of this study is to determine the best growth medium/media for propagation of Mussaenda philippica.

\section{Materials and methods}

The study was conducted at Federal College of Agriculture, Akure. The site lies between longitudes $3^{\circ} 50^{\prime}$ and $3^{\circ} 52^{\prime}$ South and latitude $7^{\circ} 23^{\prime}$ and $7^{\circ} 25^{\prime}$ North. The soil was sandy loam. Polythene bags were thoroughly filled with the different growth medium and Mussaenda philippica cuttings (5 $\mathrm{cm}$ long) were planted at an angle of $45^{\circ} \mathrm{C}$. Growth media samples from each treatment were collected for chemical analysis.

The $\mathrm{pH}$ was determined using a glass electrode $\mathrm{pH}$ meter in both distilled water and $0.01 \mathrm{M} \mathrm{CaCl}_{2}$ solution, using 1:2 growth medium : $\mathrm{CaCl}_{2}$ solution (Thomas, 1996), growth medium organic carbon was determined by the chromic acid digestion method (Walkley and Black, 1934). The total Nitrogen concentration was determined by macro-Kjeldhal method (Bremner, 1996), and the available $\mathrm{P}$ was extracted by Bray -1 method (Kuo, 1996) and determined using spectrometer model 721. Exchangeable $\mathrm{K}, \mathrm{Ca}, \mathrm{Na}$, and $\mathrm{Mg}$ were extracted with neutral ( $\mathrm{pH} 7$ ) solution of $1 \mathrm{~N} \mathrm{NH}_{4} \mathrm{OAc}, \mathrm{K}, \mathrm{Ca}$ and $\mathrm{Na}$ were determined using the flame photometer and $\mathrm{Mg}$ by the atomic absorption spectrophotometer.

The experiment was laid out in Completely Randomized Design (CRD) and each treatment consisting of five plants; replicated four times, thus 20 plants per growth medium and a total of 180 Mussaenda philippica cuttings were used for the nine different growth media i.e. Topsoil (T1), Poultry manure (T2), River sand (T3), Sawdust (T4), Topsoil + Poultry manure (T5), Topsoil + Sawdust (T6), Topsoil + River sand + Poultry manure (T7), Topsoil + Sawdust + Poultry manure (T8), Topsoil + Sawdust + Poultry manure + River sand (T9). The area was protected with palm front, six (6) pillars of bamboo and covered with wire mesh, with an elevation area of $6 \times 3.5$ square meters. Polythene bags at a spacing of $30 \mathrm{~cm} \times 30 \mathrm{~cm}$ inter and intra row respectively. Apron stars (fungicide) was used to treat the cuttings against fungi attack. At 6 weeks after 
planting (WAP), there was an application of an insecticide, Aldrex 40, against perforated leaves of Mussaenda philippica. Weeding was carried out by hand rouging.

Data were collected on growth parameters of number branches, leaves, roots, plant height and root length from four weeks after planting (WAP) and subsequent reading were taken at two weeks interval for fourteen weeks and the data was analyzed using t-test of SPSS 17.0 Statistical package.

\section{Results and discussion}

The chemical analysis of the growth media used for the experiment (Table 1) indicated that, all the growth media have nutrients for plant survival except river sand. The $\mathrm{pH}$ of all the media was generally neutral except T7, T3 and T9 that ranged between 6.2 to 6.8 (acidic), the movement of nutrients to plants from growth media is a function of the changes in the growth media $\mathrm{pH}$, which its increase or decrease in the growth media $\mathrm{pH}$ has direct effect on the growth and development of the plant. Changes in the range of optimum $\mathrm{pH}$ could obviously damage the roots and therefore decrease the nutrients availability. The $\mathrm{pH}$ of all the growing media used for this experiment fell between $6.2-7.6$ which according to Awang et al. (2010) that the best $\mathrm{pH}$ range $(5.9-7.0)$ is good for better growth and development, however increase in $\mathrm{pH}$ (acidic) induced reduction in Nitrogen and Phosphorous content of growth medium (Altland, 2006) as this was most evidenced in T3 (River sand - 6.2). Percent Organic Carbon and Nitrogen was positively correlated in all media except in Topsoil with the least, however river sand presented the poorest nutrients which is predominantly quartz $\left(\mathrm{Sio}_{2}\right)$. Phosphorous and Nitrogen was highest as expected in Topsoil + Sawdust +Poultry manure (T8) which might be due to its highest $\mathrm{pH}$ (7.6).

Table 1. Chemical analysis of media used for the experiment.

\begin{tabular}{|c|c|c|c|c|c|c|c|c|c|}
\hline \multirow{2}{*}{ Treatments } & \multirow{2}{*}{ Growth media } & \multirow{2}{*}{ pH (1:2) } & \multirow{2}{*}{$\% \mathrm{C}$} & \multirow{2}{*}{$\% \mathbf{N}$} & \multirow{2}{*}{$\mathbf{P}(\mathbf{p p m})$} & $\mathbf{K}^{+}$ & $\mathrm{Na}^{+}$ & $\mathbf{C a}^{++}$ & $\mathrm{Mg}^{++}$ \\
\hline & & & & & & \multicolumn{4}{|c|}{$\mathrm{Cmol} / \mathrm{kg}$} \\
\hline $\mathrm{T} 1$ & Topsoil & 7.4 & 0.35 & 0.04 & 11.53 & 0.31 & 2.50 & 2.00 & 1.20 \\
\hline $\mathrm{T} 2$ & Poultry manure & 7.3 & 2.21 & 0.22 & 112.45 & 0.73 & 2.16 & 4.80 & 2.00 \\
\hline $\mathrm{T} 3$ & River sand & 6.2 & - & - & - & 0.18 & 0.01 & 0.03 & 0.02 \\
\hline $\mathrm{T} 4$ & Sawdust & 7.1 & 30.91 & 0.34 & 4.04 & 8.31 & 2.0 & 1.8 & 0.8 \\
\hline $\mathrm{T} 5$ & Topsoil + Poultry manure & 7.4 & 2.48 & 0.25 & 105.33 & 1.28 & 2.64 & 3.80 & 1.8 \\
\hline T6 & Topsoil + Sawdust & 7.2 & 1.66 & 0.17 & 41.34 & 0.58 & 2.09 & 2.20 & 1.60 \\
\hline $\mathrm{T} 7$ & $\begin{array}{l}\text { Topsoil + River sand + } \\
\text { Poultry manure }\end{array}$ & 6.7 & 0.80 & 0.08 & 28.19 & 0.58 & 1.67 & 3.90 & 1.70 \\
\hline $\mathrm{T} 8$ & $\begin{array}{l}\text { Topsoil }+ \text { Sawdust }+ \text { Poultry } \\
\text { manure }\end{array}$ & 7.6 & 3.20 & 0.71 & 120 & 0.65 & 3.06 & 2.30 & 1.80 \\
\hline T9 & $\begin{array}{l}\text { Topsoil+ Sawdust + Poultry } \\
\text { manure + River sand }\end{array}$ & 6.8 & 6.88 & 0.69 & 102.42 & 1.84 & 3.20 & 3.00 & 2.20 \\
\hline
\end{tabular}

Table 2. *Effects growth media on the number of branches, leaves, root, plant heights and root length (cm) in of Mussaenda philippica.

\begin{tabular}{lllllll}
\hline Treatments & Growth media & Branches & Leaves & Root & Plant heights & Root length \\
\hline T1 & Top soil & 2 & 6 & 1 & 1.88 & 2.5 \\
T2 & Poultry manure & 2 & 7 & 2 & 1.74 & 2.9 \\
T3 & River sand & 1 & 2 & 1 & 1.2 & 1.7 \\
T4 & Sawdust & 1 & 4 & 1 & 1.70 & 5.1 \\
T5 & Topsoil + Poultry manure & 3 & 8 & 3 & 1.91 & 4.1 \\
T6 & Topsoil + Sawdust & 1 & 7 & 2 & 1.86 & 3.2 \\
T7 & Topsoil + River sand +Poultry manure & 2 & 5 & 2 & 1.81 & 3.6 \\
T8 & Topsoil + Sawdust +Poultry manure & 3 & 9 & 4 & 1.94 & 4.2 \\
T9 & Topsoil + Sawdust +Poultry manure + & 2 & 6 & 2 & 1.73 & 4.0 \\
& River sand & & & & & \\
\hline
\end{tabular}

*Average of four replicates 
Mean maximum number of branches indicated vigorous vegetative plant growth. Nutrient rich growth medium promotes the growth of plant. Table 2 showed that treatments $\mathrm{T} 5$ and $\mathrm{T} 8$ produced maximum number of branches (3), statistically, this was also confirmed (Table 3), however T8 (29.300) had a positive significant $(p<0.0001)$ increased effect on the number of branches than T5, this could be due to more nutrients being supplied by the combination of topsoil + sawdust + poultry manure (T8), similar finding was also reported by Riaz et al. (2008) in ornamental plants having much increased side branches in coconut compost growing medium in combination with silt + leaf manure. T3, T4, and T6 produced the least mean branches (Table 2), but (Table 3) indicated that T3; statistically had the most negative (-4.940) significant $(p<0.005)$ effect on the branches when compared with other growth media, the reason being that river sand generally, from chemistry point of view is predominantly quartz $\left(\mathrm{SiO}_{2}\right)$ which ordinarily has no nutritional value, but it depends on the site basement complex where the river sand was collected which might consist very small particles of silt or clay, the chemistry of river sand (Table 2) supported the above explanation, however the physical property of the river sand in term of its large macropores could enhanced nutrient movement.

Table 3. t-Test of effect of planting media on the number of branches in Mussaenda philippica.

\begin{tabular}{llll}
\hline Treatments & Growth media & t & Sig. (2-tailed) \\
\hline T1 & Top soil & 1.629 & 0.164 \\
T2 & Poultry Manure & -0.940 & 0.390 \\
T3 & River sand & $-4.940^{* *}$ & 0.004 \\
T4 & Sawdust & $-3.115^{*}$ & 0.026 \\
T5 & Topsoil + Poultry manure & $5.060^{* *}$ & 0.004 \\
T6 & Topsoil + Sawdust & $-2.112^{*}$ & 0.037 \\
T7 & Topsoil + River sand + Poultry manure & -2.191 & 0.080 \\
T8 & Topsoil + Sawdust + Poultry manure & $29.300^{* * *}$ & 0.0001 \\
T9 & Topsoil + sawdust + Poultry manure + River sand & -1.191 & 0.077 \\
\hline
\end{tabular}

***Significant at $p=0.0001, * *$ Significant at $p<0.005, *$ Significant at $p<0.05$

Table 4. t-Test of effect of planting media on the number of leaves in Mussaenda philippica.

\begin{tabular}{llll}
\hline Treatment & Growth media & t & Sig. (2-tailed) \\
\hline T1 & Top soil & 0.542 & 0.611 \\
T2 & Poultry manure & 0.504 & 0.636 \\
T3 & River Sand & $-17.393^{* * *}$ & 0.0001 \\
T4 & Sawdust & $-5.966^{* *}$ & 0.002 \\
T5 & Topsoil +Poultry manure & $2.712^{*}$ & 0.042 \\
T6 & Topsoil + Sawdust & 1.085 & 0.328 \\
T7 & Topsoil + River sand + Poultry manure & -1.195 & 0.286 \\
T8 & Topsoil + Sawdust + Poultry manure & $8.000^{* * *}$ & 0.0001 \\
T9 & Topsoil + sawdust +Poultry manure + River sand & -0.889 & 0.415 \\
\hline
\end{tabular}

*** Significant at $p=0.0001, * *$ Significant at $p<0.005, *$ Significant at $p<0.05$.

Leaves in plant as photosynthetic apparatus are vital to plant survival, thus influenced by environmental and soil condition including growing media (Mehmood et al., 2013). Data containing the mean number of leaves (Table 2 and 4). Table 2 indicated that treatment T8 had the highest mean number of leaves (9), followed by T5, while the least mean number of leaves was the river sand (T3), statistically (Table 4), T8 had the most pronounced positive significant $(p=0.0001)$ effect, followed by T5 $(p<0.05)$, while T3 $(-17.393)$ at $(p=0.0001)$ had a negative effect on mean number of leaves. The reason for the best performance of T8 was the high nitrogen and phosphorous (Table 1), especially nitrogen which plays a vital role in the vegetative growth of the plant, this was also supported by Joiner and Nell (1982). The plant in this growth medium T8 (Table 2) also had the highest mean number of roots which was an indication of high adsorption rate of available nutrients resulting in larger number of leaves, this assertion was also found by Verdonck and Boodt (1981) when he experimented pine 
leaf mould growth medium for Azaleas and Rhododendrons.

Table 2 and 5 indicated data on mean number of roots and its t- test statistical analysis. The t- test statistical analysis (Table 5) showed that the growing media had both positive and negative effects with river sand (T3; 5.200) had significant $(p<0.005)$ negative effect, however, T8 $(2.800)$ had positive significant $(p<0.05)$ on the mean number of roots. Mean maximum number of roots (4) was counted on T8 followed by T5 (3) and the mean minimum number of roots on T3 substrate/growth medium (Table 2). Maximum number of roots was an indication of essential nutrients as contained in $\mathrm{T} 8$ on the surface of the medium (T8), this nutrients in T8 was in contrast in T3 (Table 1), hence T8 facilitated the efficient taking up of the plant nutrient needed to produce more roots, similar result was observed by Merrow (1995) when he used Sedge peat growth medium for Ravenea rivularis (Majesty plant).

Mean maximum increase $(1.94 \mathrm{~cm})$ in plant height (Table 2) was observed in T8 and followed by T5 (1.91 $\mathrm{cm})$. The least plant height $(1.2 \mathrm{~cm})$ was observed in T3 (Table 2). All the treatments growing media recorded non - significant (Table 6) effect, except T3 that indicated negative significant $(p<0.0005)$ effect on plant height. The growth media generally affect the plant height, Table 2, showed that the use of different growth media affect the plant height differently, this type of growth in height of plant was also observed by Dubsky and Sramek (2008), and the increased of plant height as displayed (Table 2) for T8 and T5 was as a result of availability of the essential nutrients essential for plant to attain maximum height and development was also supported by Treder (2008).

Table 5. t-Test of effect of planting media on the number of roots in Mussaenda philippica.

\begin{tabular}{llll}
\hline Treatments & Growth media & t & Sig. (2-tailed) \\
\hline T1 & Top soil & 1.58 & 0.881 \\
T2 & Poultry manure & -8.94 & 0.421 \\
T3 & River sand & $-5.200^{* *}$ & 0.003 \\
T4 & Sawdust & -1.739 & 0.142 \\
T5 & Topsoil +Poultry manure & 1.900 & 0.116 \\
T6 & Topsoil + Sawdust & 0.894 & 0.412 \\
T7 & Topsoil + River sand +Poultry manure & 0.332 & 0.753 \\
T8 & Topsoil + Sawdust + Poultry manure & $2.800^{*}$ & 0.038 \\
T9 & Topsoil + sawdust + Poultry manure + River sand & 0.800 & 0.460 \\
\hline
\end{tabular}

$* * *$ Significant at $p=0.0001, * *$ Significant at $p<0.005, *$ Significant at $p<0.05$.

Table 6. t-Test of effect planting media on the plant height $(\mathrm{cm})$ of Mussaenda philippica.

\begin{tabular}{llll}
\hline Treatments & Growth media & t & Sig. (2-tailed) \\
\hline T1 & Top soil & 1.138 & 0.307 \\
T2 & Poultry manure & 0.302 & 0.775 \\
T3 & River sand & $-5.809^{* *}$ & 0.002 \\
T4 & Sawdust & 2.89 & 0.784 \\
T5 & Topsoil + Poultry manure & 0.583 & 0.585 \\
T6 & Topsoil + Sawdust & 1.557 & 0.180 \\
T7 & Topsoil + River sand + Poultry manure & 1.738 & 0.143 \\
T8 & Topsoil + Sawdust + Poultry manure & 0.585 & 0.584 \\
T9 & Topsoil + Sawdust +Poultry manure + River sand & 0.248 & 0.814 \\
\hline
\end{tabular}

** Significant at $p<0.005$.

The mean maximum root length $(5.1 \mathrm{~cm})$ was observed in T4, followed by $\mathrm{T} 8(4.2 \mathrm{~cm})$ and the least T3 $(1.7 \mathrm{~cm})$ (Table 2). The t-test analysis (Table 7) showed that T1, T3, T4 and T5 had significant effects on the root length, while T1 had negative $(p<0.05)$, T3 had negative $(p=0.001), \mathrm{T} 4 \mathrm{had}$ the most pronounced positive significant $(p=0.0001)$ and T5 had positive significant $(p<0.05)$ effect on the roots length. It was also noted that sawdust had a highly significant effect on the proliferation of the roots; the sawdust effect was due largely on the internal heat effect of sawdust which definitely triggered the increase in root length (Shah, 2006). 
Table 7. t-Test of effect planting media on the root length $(\mathrm{cm})$ of Mussaenda philippica.

\begin{tabular}{llll}
\hline Treatment & Growth media & t & Sig. (2-tailed) \\
\hline T1 & Top soil & $-2.724 *$ & 0.042 \\
T2 & Poultry manure & -1.027 & 0.352 \\
T3 & River sand & $-7.097 * *$ & 0.001 \\
T4 & Sawdust & $4.604 * * *$ & 0.0001 \\
T5 & Topsoil + Poultry manure & $3.081^{*}$ & 0.027 \\
T6 & Topsoil + Sawdust & -1.28 & 0.903 \\
T7 & Topsoil + River sand + Poultry manure & 0.934 & 0.393 \\
T8 & Topsoil + Sawdust + Poultry manure & 1.765 & 0.138 \\
T9 & Topsoil + Sawdust + Poultry manure + River sand & 1.800 & 0.132 \\
\hline
\end{tabular}

$* * *$ Significant at $p=0.0001, * *$ Significant at $p<0.005, *$ Significant at $p<0.05$.

\section{Conclusion}

Generally, it was observed from the study that, each growth medium produced differential results which were relative in terms of being increased or decreased to other growth medium or media and manifested in the $\mathrm{t}$ - test analysis as positive or negative effect. The findings also indicated that, a single/sole growth medium did not produced statistically positive significant effects on all the agronomic parameters observed, but more nutrients was made available when the growth medium were combined. Finally, the investigation on the effects of different growth media on propagation of Mussaenda philippica had shown that, Topsoil + Sawdust + Poultry manure (T8) was the best among all the growth media used for propagation, because it had a more pronounced positive significant $(p=0.0001)$ effects on number of branches and leaves, and $(p<0.05)$ on number of roots.

\section{Conflict of interest statement}

Authors declare that they have no conflict of interest.

\section{References}

Altland, J. E., 2006. Substrate pH, a tricky topic, Digger. 50, 42-47.

Arbury, J., Richard, B., Deni, B., Mike, H., 1997. The Complete Book of Plant Propagation. Tounton Press, New Town, CT. pp.57-62.

Awang, Y., Shaharom, A. S., Mohamad, R. B., Selamat, A., 2010. Growth dynamics of Celosia cristata grown in cocopeat, burnt rice hull and kenaf core fiber mixtures. Am. J. Agric. Biol. Sci. 5, 70-76.

Bajaj, Y.P., 1992. Technology and Micropropagation V. Spinger Verlag, New York. pp.78-79.

Ball, V., 2003. Ball Red Book $17^{\text {th }}$ Edn. Ball Publishing, Batavia, IL. Pp.20-25.

Bremner, J. M., 1996. Total nitrogen. In: Methods of Soil Analysis, Part 3: Chemical Methods (Ed.: Sparks, D.L.). SSSA and ASA, Madison. Pp.1123-1184.
Dirr, M., Charles, W. H., Bonnie, L. D., 1987. The Reference Manual of Woody Plant Propagation from Seed to Tissue Culture. Varsity Press, Athens, GA. Pp.74-79.

Dubsky, M., Sramek, F., 2008. Crushed rock wool as a component of growing substrates. Acta Horitc. 779, $491-$ 495.

Joiner, J. N., Nell, T. A., 1982. Fired montmolillonite clay as a propagation and hydroponic growing medium. Proc. Florida State Hort. Soc. 93, 214-215.

Kuo, S., 1996. Phosphorous. In: Methods of Soil Analysis, Part 3: Chemical Methods (Ed.: Sparks, D.L.). SSSA and ASA, Madison. pp.869-920.

Kyle, L., John, K., 1996. Plants from Test Tubes: An Introduction to Micro propagation. Timber Press, Portland. pp.17-19.

Mac Donald, B., 1987. Practical Woody Plant Propagation for Nursery Growers. Timber Press, Portland. pp.21-22.

Mehmood, T., Ahmad, W., Ahmad, K. S., Shehzad, M . A., Sarwar, M. A., 2013. Comparative effect of different potting media on vegetative and reproductive growth of floral shower (Antirrhinum majus L.). Universal J. Plant Sci. 1(3), 104-111.

Merrow, A.W. 1995. Growth of two tropical foliage plants using coir dust as a container medium amendment. Hort. Technol. 5, 237-239.

Nau, J., 1996. Ball Culture Guide, the Encyclopedia of Seed Germination. Ball Publishing, Bataria, IL. 58p.

Razdan, M.K., 2003. Introduction of Plant Tissue Culture. $2^{\text {nd }}$ Edn. Agritech Publications, Shrub Oak, NY. pp.98-102.

Riaz, A., Arshad, M., Younis, A., Raza, A., Hameed, M., 2008. Effect of different growing media on the growth and flowering of Zinnia elegans cv. Blue Point. Pak. J. Bot.40, 1579-1585.

Shah, M., Khattak, A. M., Amin, N., 2006. Effect of different growing media on the rooting of Ficus binnendijkii 'Amstel queen' cuttings. J. Agric. Biol. Sci. 1(3), 15-17.

Tariq, U., Rehman, S., Aslam, M. K., Younis, A., Yaseen, M., Ahsan, M., 2012. Agricultural and municipal waste as potting media components for the growth and flowering of Dahlia hortensis 'Figaro'. Turk. J. Bot. 36, 378-388.

Thomas, G.W., 1996. Soil pH and soil acidity. In: Methods of Soil Analysis, Part 3: Chemical Methods (Ed.: Sparks, D.L.). SSSA and ASA, Madison. pp.475-490. 
Treder, J., 2008. The effects of cocopeat and fertilization on the growth and flowering of oriental lily 'star gazer'. J. Fruit Ornam. Plant Res. 16, 361-370.

Van Pattern, George, F., Alyssa, F. B., 1997. Gardening Indoors with Cuttings. Van Pattern Publishing, Washougal, WA. pp.307-400.

Verdonck, D., Boodt, M.D., 1981. The use of bark compost as a substrate for hot house plant. Mededelingen, Rijks station voor Sieplantenteelt. 54(3), 73-83.

Walkley, A., Black, I. A., 1934. An examination of the Degtajareff method for soil organic matter determination and a proposed modification of the chronic acid titration. Soil Sci. 37, 29-38.

Wilson, S. B., Stoffella, P. J., Graetz, D. A., 2002. Development of compost based media for containerized perennials. Sci. Hortic. 93, 311-320.

\section{How to cite this article:}

Okanlawon, S. O., Babatunde, K. M., Salau, M. A., Adekanmbi, O. A., Jmoh, A. R., 2016. Effects of different growth media on propagation of horticultural plant, Mussaenda philippica (Queen of Philippines). Int. J. Curr. Res. Biosci. Plant Biol. 3(7), 4-10. doi: http://dx.doi.org/10.20546/ijcrbp.2016.307.002 